\title{
Comparison of HIC Values during Train-Car Collisions
}

O. Fanta ${ }^{*}$, M. Hybner, F. Lopot, K. Jelen

Department of Anatomy and Biomechanics, Faculty of Physical Education and Sport, Charles University in Prague, Czech Republic

* Corresponding author: fantao@seznam.cz

Z. Malkovský

VÚKV a.s., Bucharova 1314/8, 15800 Prague, Czech Republic

H. Purš

Advanced Engineering, s.r.o., CAE Dep., Prague, Czech Republic

DOI: $10.2478 / \mathrm{v} 10158-011-0021-9$

\begin{abstract}
Accident statistics show that a collision of a train with a car has a significant share of the number of traffic accidents. It also ranks among the most tragic. Three crash tests were made simulating the side impact of a railway vehicle with a car on a level crossing to monitor the biomechanics of possible injury. This study pays particular attention to head injuries. Head acceleration in all three axes was captured on a mannequin during an impact with Skoda Superb and Skoda Favorit vehicles. The most common head injury criterion (HIC) was selected as a quantitative indicator for comparison. It transpired that the contact of the head with an element of the car interior, whether or not the out-of-position occurs during the impact, plays an important role in the severity of head injuries.
\end{abstract}

KEYWORDS: Biomechanics, head injury criterion, train-car collision, crash test.

\section{INTRODUCTION}

In developed countries, where the statistics of traffic accidents are processed, a number of organizations (Railway Infrastructure Administration and Railway Inspectorate in the Czech Republic, The Community of European Railway and Infrastructure Companies and European Transport Safety Council in Europe, International Union of Railways worldwide) deal with safety on trains, originating from an attempt to eliminate this kind of accident, or at least minimize them. As stated by the Railway Inspectorate of the Czech Republic, "In recent years, the Rail Safety Inspection has recorded a very high number of fatal accidents at railway crossings. While previously people died in every tenth accident at crossings, it is now every sixth accident." (Drážní inspekce, 2011) 
Almost half of all accidents take place at crossings equipped with a light signalling device, which make up only a quarter of the total number of crossings. There were 8,161 crossings under RIA administration on $31^{\text {st }}$ of December 2010, of which 4,453 were secured in the basic way with a cross and 3,708 were secured with various devices of various types and technical levels.) (Drážní inspekce, 2011). The development of accidents at level crossings (including accidents involving pedestrians, cyclists, etc.) is shown in the graph in Fig. 1a. In train collisions with a car 34 people in 240 accidents were killed in 2010, 12 persons in 99 accidents have been killed so far in the period from January to August 2011 (Policie ČR, 2011a, 2011b). In comparison with the total number of traffic accidents 75,522 in 2010 - only approximately $0.3 \%$ of them happen at crossings, but, in addition to the high mortality of such accidents, they cause the highest average financial damage, which is $275,931 \mathrm{CZK}$ for one such accident. The number of accidents at level crossings is available for the European Union, which amounted to 1355 accidents in 2006, 1295 accidents in 2007 and 1124 accidents in 2008 (European Railway Agency, 2010). A comparison with the situation in the United States is shown in Fig. 1b. In most of the cases of collisions of a train with a car there are no injuries or deaths of persons within the train, although rare cases of train derailment due to car have occurred (Leibenluft, 2008).

On the other hand, for the occupants of a car the crash is often fatal, death occuring in more than $10 \%$ of all accidents at crossings. Thorson and Lundström (1986) showed that if a car is not wedged under the front of the train locomotive, and instead is pushed to the side, there is a chance of survival. Bjornstig, Bjornstig, and Eriksson (2008) believe that such pushing can be achieved by changing the design of the front of the locomotive in order to prevent fatal collisions.

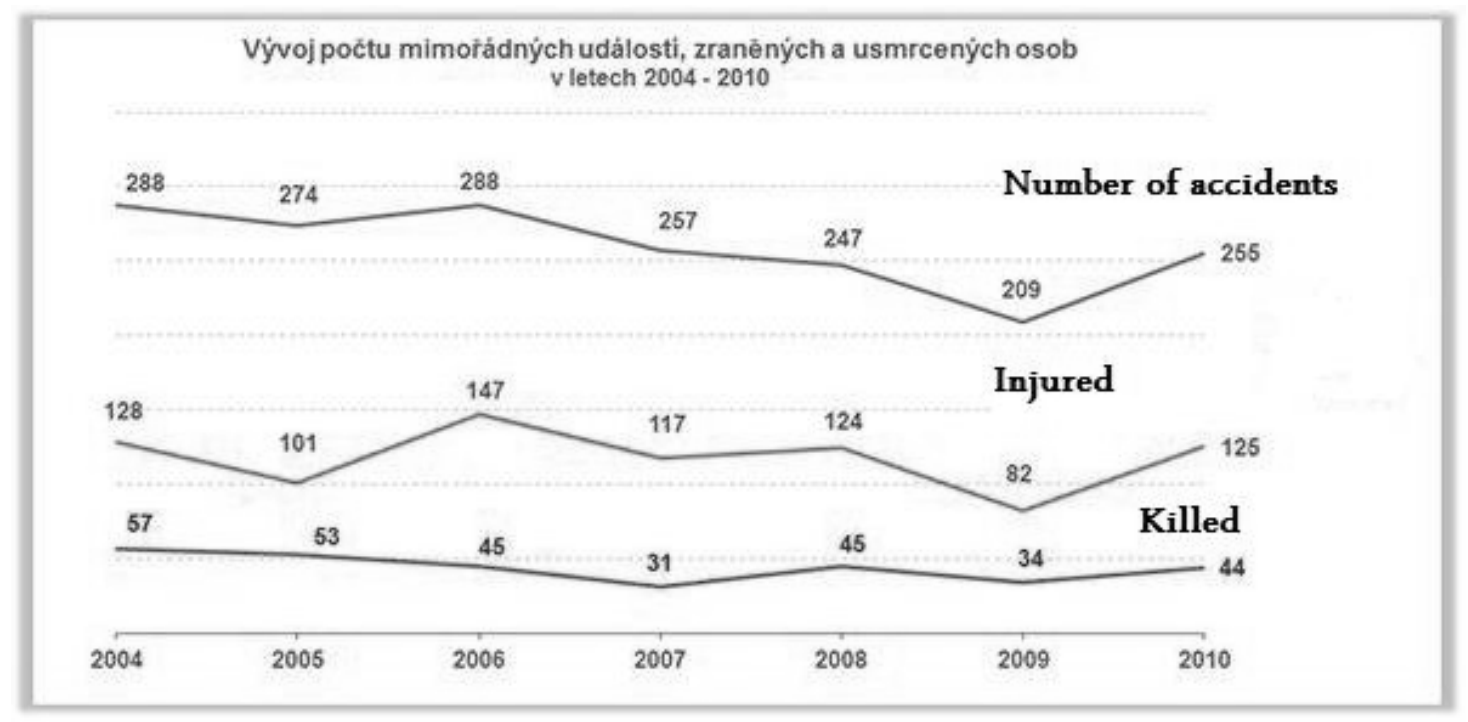

Figure 1a: Number of accidents at level crossings and deaths caused by them. Emergencies, i.e., all accidents at level crossings (including accidents involving pedestrians, cyclists, etc.) and the number of injured and killed people in the Czech Republic in 2004 to 2010 (The Railway Safety Performance in the European Union, 2010). 


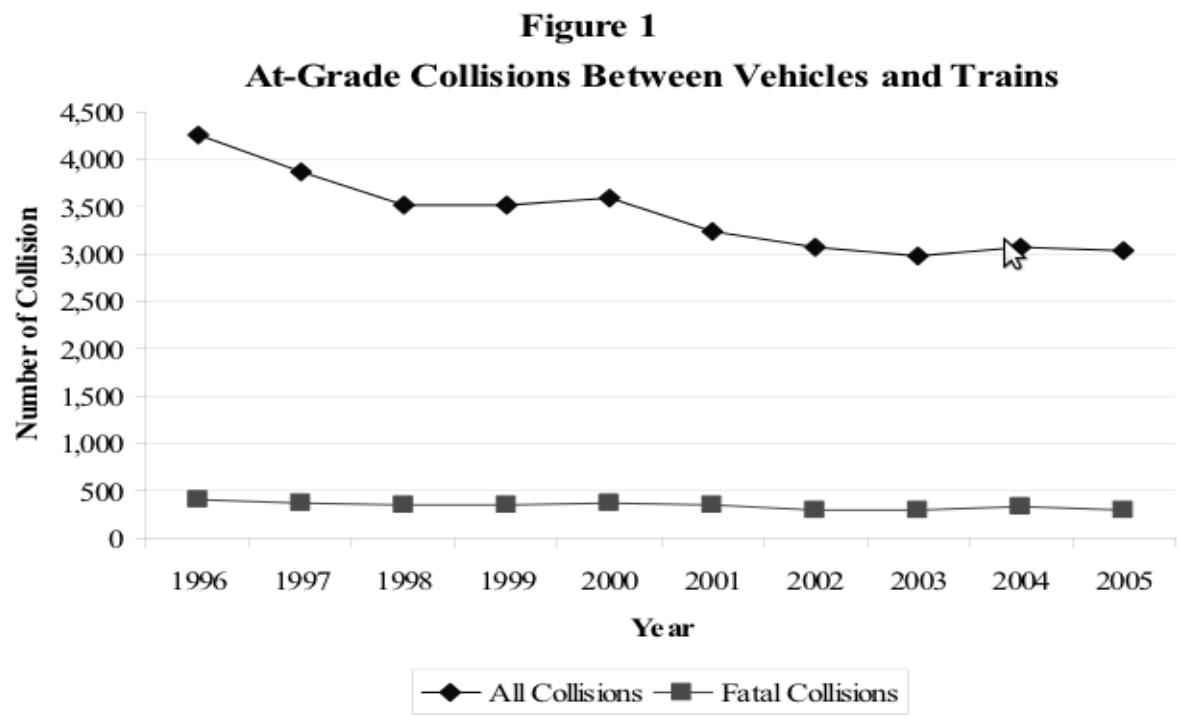

Figure 1b: Number of collisions of vehicles and trains at level crossings and deaths caused by them in the U.S. between 1996 and 2000 (Raub, 2007).

Side impacts in traffic accidents in general (not just train and car) have resulted in $20 \%$ $40 \%$ of injuries and deaths (Laberge, Bellavance, Messier, Vézina, \& Pichette, 2009). Twothirds of those concern collisions between two vehicles and one-third of cases concern hitting a stationary object (Chipman, 2004). In three-quarters of fatal collisions the direction of impact angle is between $60^{\circ}$ and $120^{\circ}$ and between $240^{\circ}$ and $300^{\circ}$, while head injuries were more frequent in the oblique impacts and chest injuries were more frequent in perpendicular impacts (Walz, Niederer, Zollinger, \& Renfer, 1977). More than 70\% of injuries in passenger cars are to passengers on the impact side (Fildes, Gables, Fitzharris, \& Morris, 2000). Use of a seat belt reduces the risk of death to $40 \%$ and risk of injury to the spleen to $76 \%$ (Reiff, McGwin, \& Rue, 2001). According to research involving 4032 accidents (Chipman, 2004) the most common serious injuries in a vehicle hit from the side were those to the neck (31\%), head (23\%), upper limbs $(15 \%)$, legs $(13 \%)$, chest (8\%), and abdomen (4\%). Iharashi, Ehama, and Sunabashiri (1998) mention that in Japan during side impacts with an AIS rating greater than 3 a passenger is most commonly injured in the head, secondly chest, then in the pelvis and the fourth most common injury is to the abdominal cavity. Additionally, they add that the head and chest injuries combined represent more than $50 \%$ of injuries of AIS 3 or higher. AIS - Abbreviated Injury Scale is a system of injury evaluation concerning its fatality. AIS 1 signifies a light injury, AIS 6 signifies a fatal injury.

The issue of side impacts has been thoroughly examined, especially concerning car to car impact or car to solid obstacle impact. Regarding the impact of very heavy objects (e.g., a train) to car, the occupants' injury biomechanics have not been published in detail.

A crash test, characterized as an encounter of a rail vehicle with a car on a level crossing, was performed in the area of CKD Kutna Hora siding in 2010. A rail vehicle - 850 Series motor vehicle - crashed sideways into Skoda Favorit and Skoda Superb cars. The occupants inside the vehicle were represented using a Manikin dummy. It was equipped with accelerometers for the detection of acceleration values for the subsequent analysis of the biomechanics of injury. 


\section{MATERIAL AND METHODS}

The whole crash test was prepared and performed by VÚKV a.s.. Advanced Engineering s.r.o. installed a dummy and took measurements from the passenger car. VÚKV a.s. took measurements from the railway vehicle.

Three crash tests were carried out within a day (average temperature, cloudy, without precipitation). The instigator of the impact was a rail vehicle - motor number 850 , $50.5 \mathrm{t}$ in weight. The rail vehicle has two standard plate bumpers in the front, $53.5 \mathrm{~cm}$ in front of the body. The subjects of the impact were 2 Skoda Favorit vehicles (green and white) with an operating curb weight of $915 \mathrm{~kg}$, produced from 1988 onwards, and 1 Skoda Superb vehicle of operating curb weight $1530 \mathrm{~kg}$, produced in 2001 . All the cars were left-hand drive. The estimated impact speed was $30 \mathrm{~km} / \mathrm{h}$ for the Skoda Favorit vehicles and $50 \mathrm{~km} / \mathrm{h}$ for the Skoda Superb vehicle. The cars were at rest, perpendicular to the direction of travel of the rail vehicle and the point of impact was in center of the vehicle, to the left side of Favorit, to the right side of Superb (see Fig. 2).
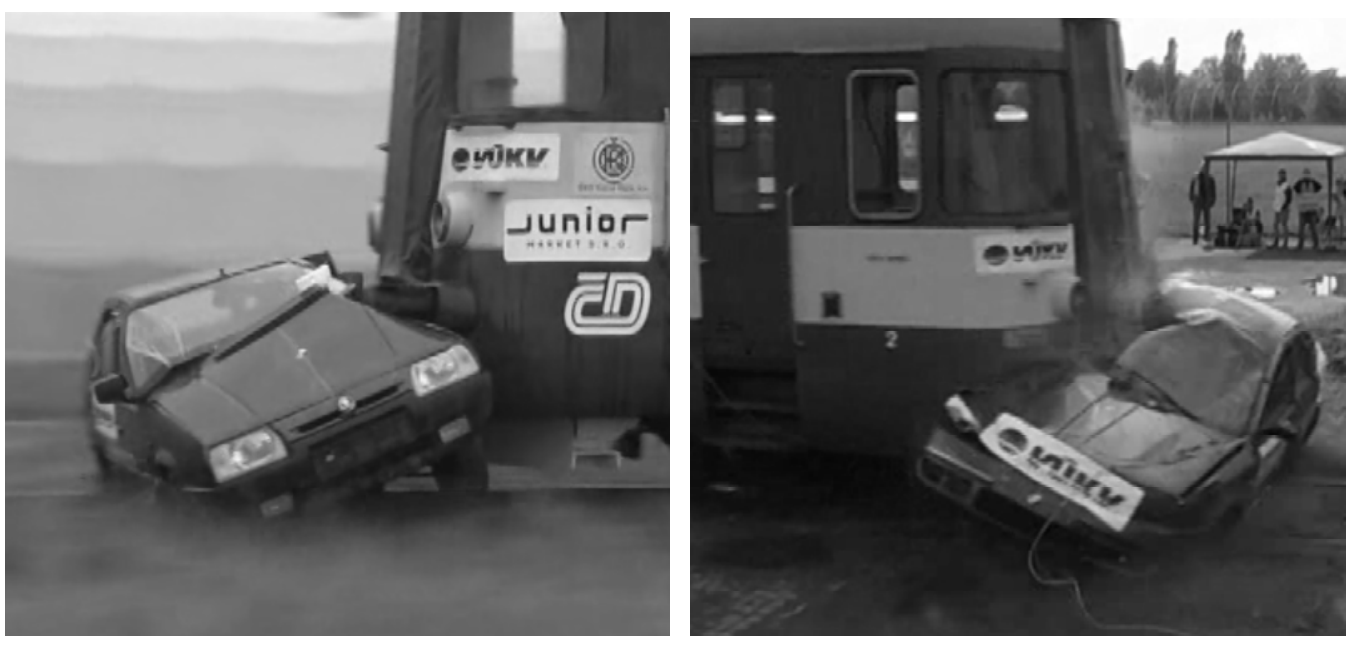

Figure 2: Detail of impact of the rail vehicle with the Skoda Favorit (left) and the Skoda Superb (right).

The rail vehicle was additionally equipped with a swept-bumper in front of the buffers during the impact with the green Skoda Superb and Favorit (see Fig. 3).

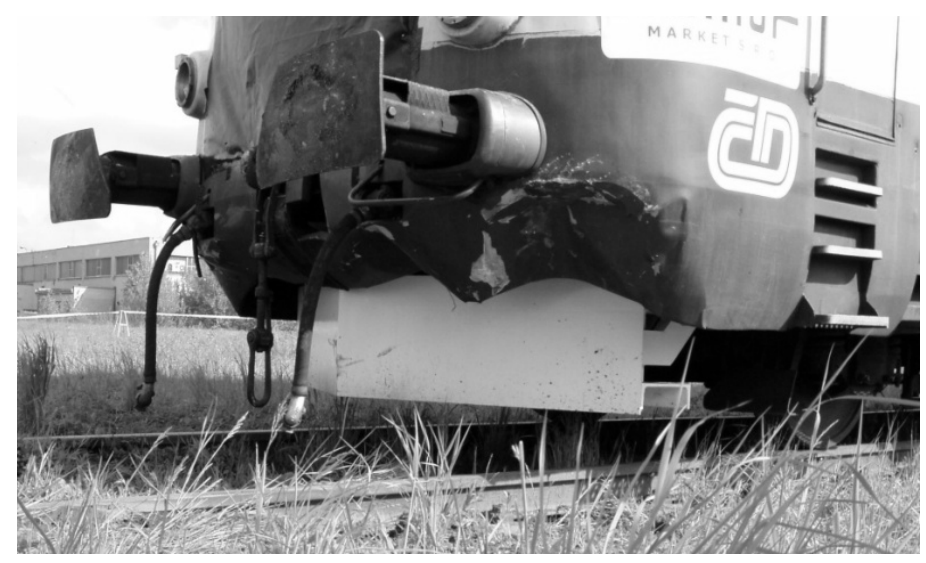

Figure 3: Detail of the front of the railway vehicle for the crash into a green Skoda Favorit and Superb. 
On the driver's seat inside the vehicle a Manikin dummy was placed and the seatbelt fastened. The dummy was equipped with a triaxial accelerometer in the head CG, a uniaxial accelerometer for measuring acceleration in the chest and a uniaxial accelerometer for measuring acceleration in the pelvis.

A PULSE Multi-analyzer system of Brüel \& Kjær brand type 3560-B with its own power supply, 5 measuring channels and one output channel was used for the measurement. A threeaxis accelerometer with a measuring range of $7500 \mathrm{~m}-2$, Brüel \& Kjær Triaxial DeltaTrontype 4504 A was mounted on this portable compact unit for measuring the acceleration of the head in $\mathrm{X}, \mathrm{Y}, \mathrm{Z}$ axes and two uniaxial accelerometers, Brüel \& KjærDeltaTrontype 4514 - B with a measuring range of $4900 \mathrm{~m}-2$, to measure the acceleration on the chest and pelvis in the $\mathrm{Y}$ axis. HyperWorks software package was used to evaluate the measured acceleration, namely the applications HyperView and HyperGraph. Data were filtered according to the EuroNCAP (European New Car Assessment Programme) (EuroNCAP, 2011) methodology after importing.

To assess the severity of injury Head Injury Criterion (HIC) was used. This is defined as:

$$
H I C=\left\{\left(t_{2}-t_{1}\right)\left(\frac{1}{t_{2}-t_{1}} \int_{t_{1}}^{t_{2}} a(t) d t\right)^{2,5}\right\}_{\max }
$$

where $a(t)$ is the resultant acceleration of the head and $t_{1}$ and $t_{2}$ are variable initial and final time intervals during which HIC reaches its maximum value.

\section{RESULTS}

\section{$\underline{\text { Skoda Favorit - Green }}$}

The real impact speed of the rail vehicle during the crash test with the green Favorit was $29.3 \mathrm{~km} / \mathrm{h}$. Initial contact was between the plate bumpers and the A and C pillars of the car (Fig. 4). Contact of the rail vehicle body with the car door space followed. No contact between the car and the plow installed on the rail vehicle was registered from an analysis of the video. The dummy was slightly diverted from the point of impact afterwards, shoulder leaning against the side of the passenger seat (Fig. 4).
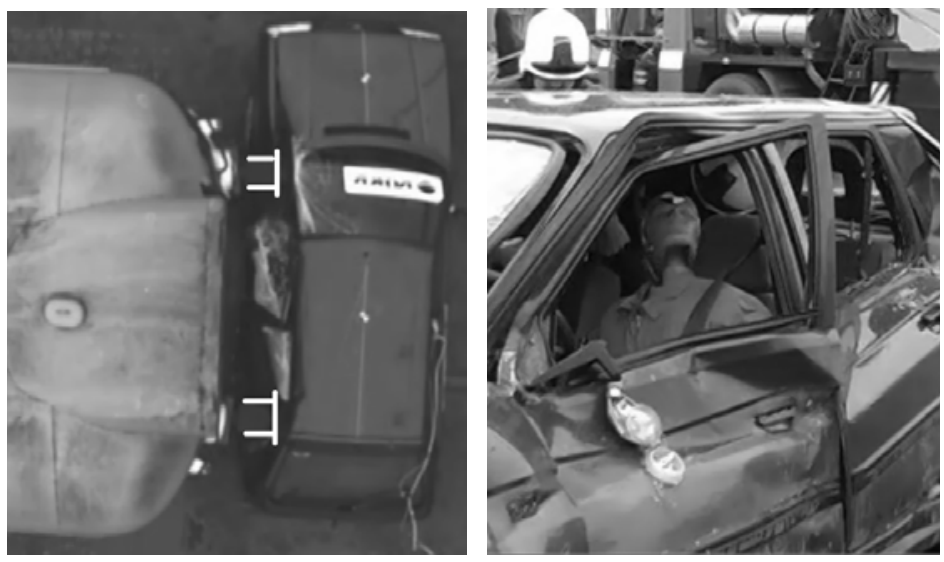

Figure 4: Detail of primary contact of the rail vehicle with the green Skoda Favorit (left), final position of a dummy after the crash test (right). 
Data from the accelerometer (see Fig. 5) was filtered using CFC 1000 filter after importing into the HyperGraph according to the methodology of Euro NCAP. CFC 1000 is characterized by the following parameters: $3 \mathrm{~dB}$ limit frequency is $1650 \mathrm{~Hz}$, stop damping is $-40 \mathrm{~dB}$ and sampling frequency is at least $10 \mathrm{kHz}$.
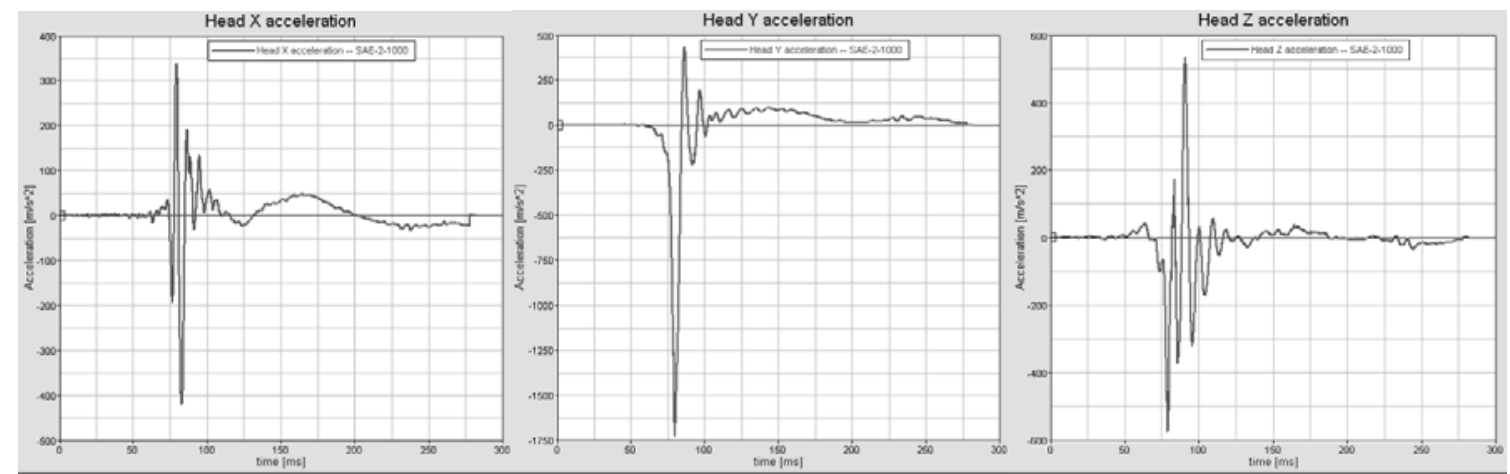

Figure 5: Recording of the accelerometers in $\mathrm{X}, \mathrm{Y}, \mathrm{Z}$ axes (left) after SAE-2-1000 filter.

Furthermore, the values in each axis were converted to a final value of the acceleration of the head (Fig. 6) and the value of HIC $=1131$ was calculated.

\section{$\underline{\text { Skoda Favorit - White }}$}

The impact speed in the crash test with the white Favorit was $25.3 \mathrm{~km} / \mathrm{h}$. The initial contact was again with the plate bumpers into the $\mathrm{A}$ and $\mathrm{C}$ pillar of the car. In this case, the addition of the plow was not used. The dummy had been diverted from the point of impact at an angle of approximately 45 degrees, elbow propped on the seat part of the passenger seat. The values of the accelerometer for individual directions were filtered by $\mathrm{CFC} 1000$ and converted to a final value of the acceleration with the calculation of $\mathrm{HIC}=469$ (Fig. 6).
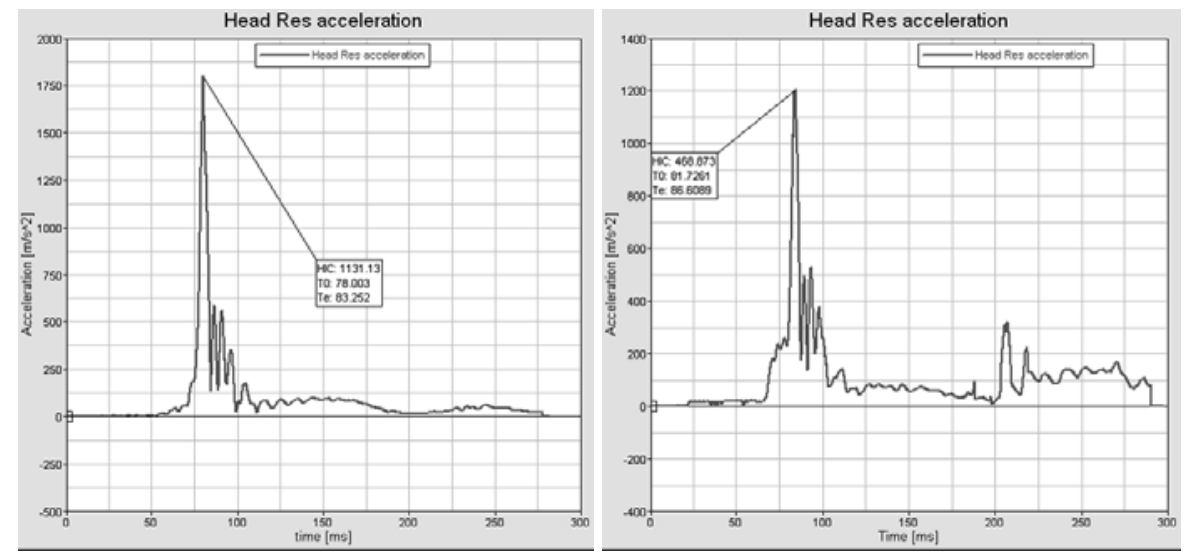

Figure 6: The resulting acceleration of the head for the green Favorit (left) and white Favorit (right). 


\section{$\underline{\text { Skoda Superb }}$}

The impact speed for the Superb was $47.5 \mathrm{~km} / \mathrm{h}$. The impact was directed onto the passenger side, one plate of the bumper to the A-pillar and the second into the glass space above the luggage compartment before the C-pillar. The rail vehicle was equipped with an additional plow and the contact of the plow with the vehicle body was clearly visible (see Fig. 7). The values of the accelerometer were filtered by CFC 1000, converted to the final value and value of $\mathrm{HIC}=17,700$ was calculated (Fig. 7).
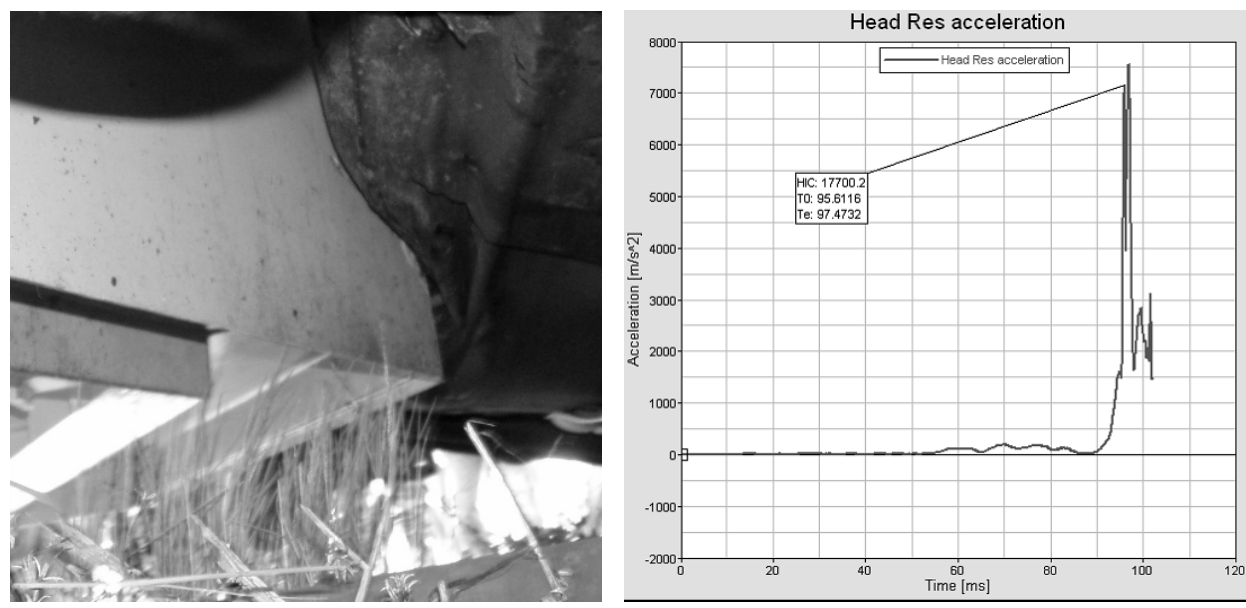

Figure 7: Detail of the rail vehicle plow contact with the car threshold (left) and the resulting acceleration of the head for Superb (right).

\section{DISCUSSION}

Cars are more usually equipped with airbags these days. According to McGwin, Metzger, and Rue (2004), passengers sitting on the affected side in vehicles equipped with side curtain airbags are at a $75 \%$ lower risk of head injuries. Side chest protection reduces the risk of injury to this body part by 68\% (McGwin et al., 2004). McCartt and Kyrychenko (2007) found that side airbags that usually combine head protection with chest protection reduce the risk of death of a car driver by $37 \%$. On the other hand, side airbags can be dangerous as well. One study (McGwin et al., 2004) found a higher relative risk (Relative Risk is defined as a ratio between event observation probability in the affected (with airbags) and unaffected (without airbags) group.) of medium (AIS $\geq 2, R R=2.75$ ) and middle (AIS $\geq$ $3, \mathrm{RR}=2.45)$ upper limbs injuries among cars with side airbags. In the crash tests carried out no airbags were used.

The dominant mechanism of injury occurs immediately after impact, when the vehicle or dummy's head is being accelerated by the force of the railway vehicle acting on the car that is standing still, and then the head impacting with the interior elements. After the initial increase and decrease in acceleration stays the acceleration value at a physiological level to a full stop.

According to the results of the accelerometers in each axis of the Skoda Favorit we can assume that there was no "hard" contact between the interior element and head of the dummy when out of position. The head hit the B-pillar of the vehicle (see Fig. 8). Due to the identical configuration of impact the size of HIC can be compared. The impact with the green Favorit was not affected by the rail vehicle plow. For the green Favorit the impact speed was $29.3 \mathrm{~km} / \mathrm{h}$ and HIC $=1131$, for the white Favorit the speed was $25.3 \mathrm{~km} / \mathrm{h}$ and HIC $=469$. 
The increase in impact speed by $4 \mathrm{~km} / \mathrm{h}$ caused a significant increase in HIC, over 2.4 times as much, and the limit value $\mathrm{HIC}=1000$ was therefore exceeded.
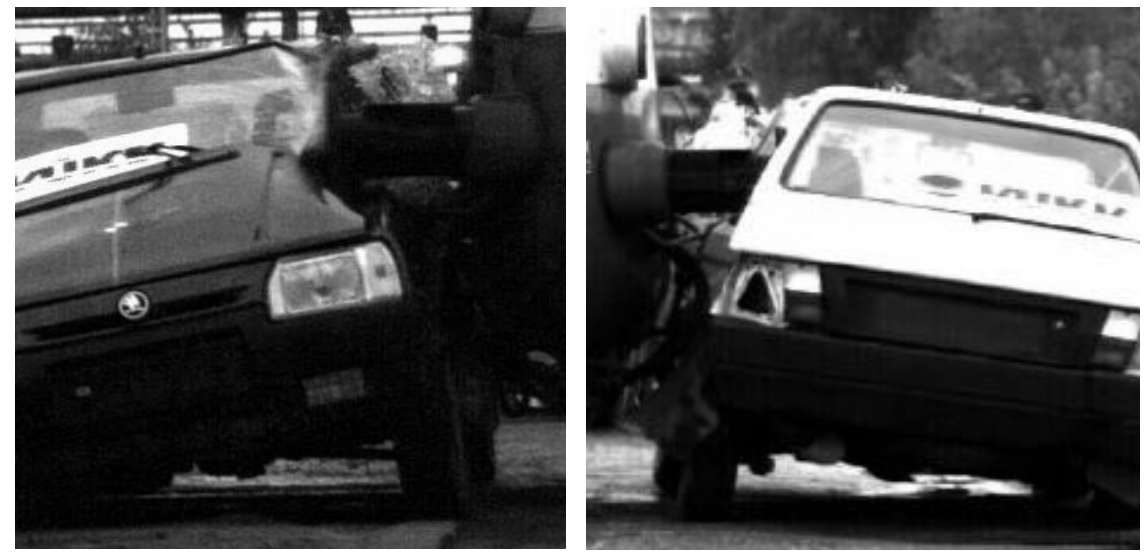

Figure 8: Contact of the head with the B-pillar, green Favorit, $75 \mathrm{~ms}$ time from initial contact (left) and head contact with the B-pillar, white Favorit, time $85 \mathrm{~ms}$ from the initial contact (right).

For the Skoda Superb car the crash test came out negative. It can not be compared directly with the Favorit vehicles, because the impact speed was $47.5 \mathrm{~km} / \mathrm{h}$, i.e., $40 \%$ higher, but the HIC $=17700$ greatly exceeded the limit value of 1000 . This high value was caused by a "hard" contact with the interior element in an out-of-position during impact. Although the impact was with the side opposite that of the driver, restraint systems had not kept the dummy in a proper position and the head probably hit the inner side panel of right front door (see Fig. 9).
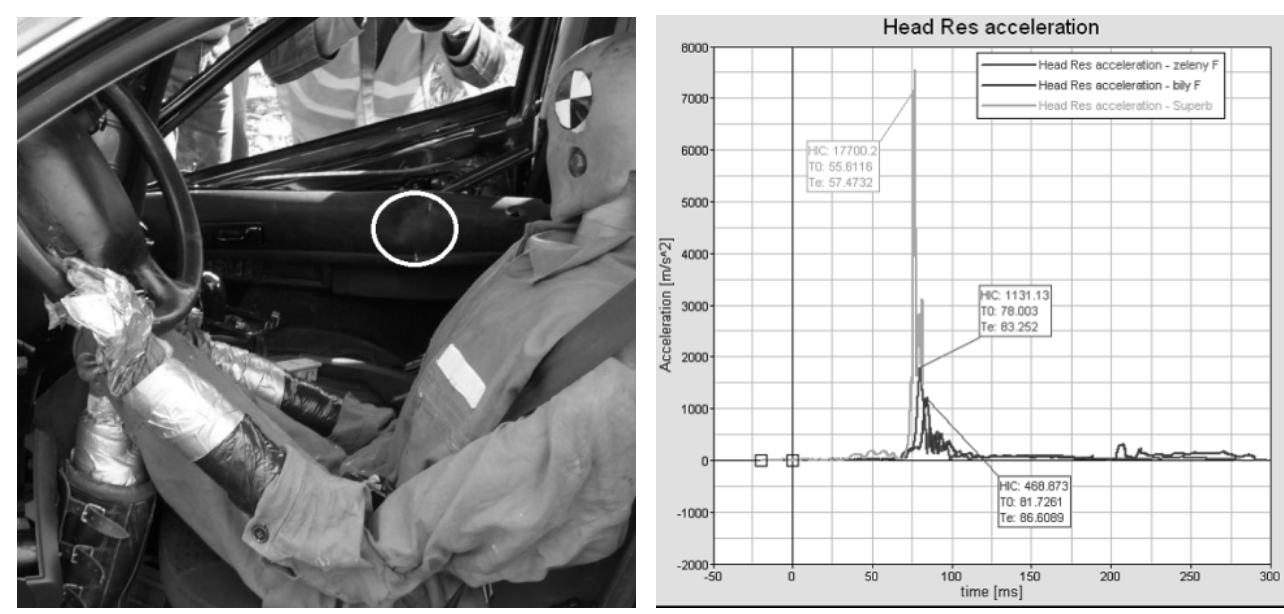

Figure 9: Probable point of contact of the head with door panel (left), and a comparison of the resulting accelerations (right).

\section{CONCLUSION}

The severity of injuries in the crash of a train with a car is obvious. Side impact with such a heavy object is destructive. During side impact on the driver's side there is often contact of the driver's head with the B-pillar. The severity of the injury is then dependent on the speed of the impact. In crash tests with the Favorit cars it has been shown that with an increasing 
impact velocity the HIC also sharply increases. The situation could be positively affected by the use of side and curtain airbags, which significantly reduce the impact strength. During the impact with the Superb on the passenger side there was probably the out-of-position and therefore a very high HIC. This situation would again be improved with side airbags, even if they were not tested in this particular situation. A negative effect can be also expected, due to the delayed contact of the head with the airbag (due to the distance to the right side of the car). For this reason car manufacturers are trying to have occupants remain in the inposition during an accident.

\section{ACKNOWLEDGEMENTS}

This paper was created with support of following project: MPO project TIP, Nr. FR-TI1-113, GAUK 111310, GAČR P 407/10/1624 and SVV-2011-263 601.

\section{REFERENCES}

Bjornstig, U., Bjornstig, J., \& Eriksson, A. (2008). Passenger car collision fatalitieswith special emphasis on collisions with heavy vehicles. Accid Anal Prev, 40(1), 158-166.

Drážní inspekce. (2011). Železniční přejezdy. From http://www.dicr.cz/zeleznicni-prejezdy

EuroNCAP. (2011). The tests explained Euro NCAP - For safer cars crash test safety rating.

European Railway Agency. (2010). The Railway Safety Performance in the European Union. 49. Retrieved from http://www.era.europa.eu/

Fildes, B., Gables, H. C., Fitzharris, M., \& Morris, A. P. (2000). Determining Side Impact Priorities Using Real-World Crash Data and Harm. Presented - IRCOBI Conference.

Chipman, M. L. (2004). Side Impact Crash Factors Affecting Incidence and Severity: Review of the Literature. Traffic Injury Prevention, 5(1), 67-75.

Iharashi, T., Ehama, M., \& Sunabashiri, Y. (1998). Development of Side Impact Airbag System for Head Chest Protection. Presented at the The 16th Int.Tech.Conf., Ontario.

Laberge, N. C., Bellavance, F., Messier, S., Vézina, L., \& Pichette, F. (2009). Occupant injury severity from lateral collisions: Journal of Safety Research, 40, 427-435.

Leibenluft, J. (2008). Why Do Trains Go off the Tracks? From http://www.slate.com/

McCartt, A. T., \& Kyrychenko, S. Y. (2007). Efficacy of side airbags in reducing driver deaths in driver-side car and SUV collisions. Traffic Inj Prev, 8(2), 162-170.

McGwin, G., Jr., Metzger, J., \& Rue, L. W., 3rd. (2004). Influence of side airbags on the risk of head and thoracic injury after motor vehicle collisions. J Trauma, 56(3), 512-516.

Policie ČR. (2011a). Informace o nehodovosti na pozemních komunikacích České republiky za leden až srpen 2011. Retrieved from www.policie.cz/ 
Policie ČR. (2011b). Přehled o nehodovosti na pozemních komunikacích v ČR za rok 2010.

The Railway Safety Performance in the European Union. (2010). Luxembourg: European Railway Agency Retrieved from http://www.era.europa.eu.

Raub, R. A. (2007). Examination of Vehicle Crashes Nationally at Highway-Rail Grade Crossings. Retrieved from http://www.oregonite.org/2007D6/

Reiff, D. A., McGwin, G., Jr., \& Rue, L. W., 3rd. (2001). Splenic injury in side impact motor vehicle collisions: effect of occupant restraints. J Trauma, 51(2), 340-345.

Thorson, J., \& Lundström, N. G. (1986). Crossing safety. Int Railway J, 17-18.

Walz, F., Niederer, P., Zollinger, U., \& Renfer. (1977). A Belted Occupants in Oblique and Side Impacts. Presented at the 3rd IRCOBI, Cologne, Germany.

The article was produced under the support of the project

Transport R \& D Centre ( CZ.1.05/2.1.00/03.0064 ). 